\title{
Influence of Nigella sativa Oil on Growth Performance and Feed Utilization and Comparison of different Non-Linear Functions against Linear Model to Describe the Growth Curve in Nile Tilapia El-Moghazy, M. M. ${ }^{1}$; M. A. A. Mostafa ${ }^{2}$ and A. S. Shosha ${ }^{3}$ \\ ${ }^{1}$ Department of Animal Production, Faculty of Agriculture, Damietta University, Egypt. \\ ${ }^{2}$ Department of Production Research and Aquaculture Systems, Central Laboratory for Aquaculture Research (CLAR), Agricultural Research Center, Egypt. ${ }^{3}$ Egyptian Plant Quarantine (Port Said), Egypt. \\ *Corresponding Author (Mostafa El-Moghazy) E. Mail Address: el-moghazymm@yahoo.com.
}

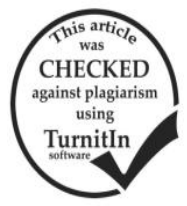

\section{ABSTRACT}

This study was conducted to evaluate the effects of different levels from Nigella sativa oil on growth performance and feed utilization and comparison of different nonlinear functions against linear model to describe the growth curve in Nile tilapia in order to select the best function. Nigella sativa oil was added at $1 \mathrm{ml}, 2 \mathrm{ml}$ and $3 \mathrm{ml} / 1010 \mathrm{~g}$ diet to Nile tilapia diets based control diet and each diet was fed in two replicates during the period from 21/10/2014 to 7/4/2015. Winter experiment started at 27/1/2015 as the amount of feed decreased to be $5 \mathrm{~g} /$ tank every 2 days to study the effect of Nigella sativa oil on fish resistance to the decrease in bodyweight during winter season. Nigella sativa oil in Tilapia rations had significant effect on the different body weights. Specific growth rate did not affect significantly by elevated Nigella sativa oil levels except specific growth rate between 8 and 10 weeks $(\mathrm{p}=0.050)$, also, condition factor did not affect significantly except initial condition factor and after 12, 14, 16 and 22 weeks. Increasing the level of Nigella sativa oil in fish diet improved body length and body depth significantly. Furthermore, Nigella sativa oil had significant effect on feed intake and feed conversion ratio. In connection to non linear models and growth curve description, Weibull and Morgan-Mercer-Flodin equations gave the highest accuracies followed by Von Bertalanffy and linear regression. The present results showed that inclusion of Nigella sativa oil in Nile tilapia (Oreochromis niloticus) diets improved growth performance and feed utilization relatively. Regarding growth curve, Weibull and Morgan-Mercer-Flodin models were the best equations to describe growth curve.

Keywords: Nigella sativa oil; Nile tilapia; Feed utilization; Non linear models; Growth curve.

\section{INTRODUCTION}

The ability of tilapia (Oreochromis niloticus) to reproduce easily, environmental stress tolerate and grow at a fast rate has made it an important fish in aquaculture production (El-Sayed, 2006). In Southeast Asia and Middle East Nigella sativa plants were used to promote fight disease and health. It is called Kalonji in South Asia and its Arabic name is Habat-ul-Sauda, while its English name is Black cumin (Nadkarni, 1976). The active constituents of Nigella sativa are volatile oil, P-cymene, d-limonene, terpene and unsaturated ketone (Kapoor,1990). Nowadays, medicinal herbs are becoming more popular than ever before as far as the possible adverse effects of synthetic drugs are concerned (Rawling et al., 2009; Bilen et al., 2011, 2013 and 2014). Several studies demonstrated positive effect of medical herbs and oil on growth performance and feed utilization in different types of fish (Dias, 2002; Metwally, 2009; Abdelwahab and El-Bahr, 2012; Sönmez et al., 2015).In connection to growth curve, numerous growth equations have been fitted to describe the nonlinear relationship between growth and age of animal such as Brody, Morgan-Mercer-Flodin, weibull, Gompertz, Logistic and Von Bertalanffy models (Tekel et al,2005;Tariq et al., 2013; Sieklicki et al., 2016).The objective of the present study is to investigate the effect of different dietry levels of Nigella sativa oil on growth performance and feed utilization in Nile tilapia (Oreochromis niloticus) and comparison of different nonlinear functions to describe growth curve against linear function.

\section{MATERIALS AND METHODS}

\section{Experimental design and procedure:}

This experiment was carried out at Animal Production Laboratory, Animal Production Department; Faculty of Agriculture, Damietta University during the period from $21 / 10 / 2014$ to $7 / 4 / 2015$. Winter experiment started at $27 / 1 / 2015$ as the amount of feed decreased to be $5 \mathrm{~g} /$ tank every 2 days. A total of 8 experimental fiberglass tanks were used in the present study with dimensions 70 $\mathrm{cm}$ length, $30 \mathrm{~cm}$ width and $50 \mathrm{~cm}$ height with capacity about 60 liters of water. Oxygen supply was through compressor air. Tanks are cleaned twice weekly before partial replacing $(75 \%)$ of water for removing the faeces.

The water source was Chlorine-free tap water. The lighting period in lab was 12 hours. A total of 120 Nile tilapia (Oreochromis niloticus) fingerlings were obtained from special hatchery located in Faraskour-Damietta and divided to four groups (two replicates treatment) and distributed to the tanks (15 fingerlings in each tank).

\section{Experimental diets:}

Four experimental diets were mixed as following:

1- Control treatment contained $800 \mathrm{~g}$ diet (21\% protein) $+200 \mathrm{~g}$ fish powder $(65 \%$ protein $)+10 \mathrm{~g}$ black honey.

2- TR1 contained $800 \mathrm{~g}$ diet $(21 \%$ protein $)+200 \mathrm{~g}$ fish powder $(65 \%$ protein $))+10 \mathrm{~g}$ black honey $+1 \mathrm{ml}$ Nigella sativa oil.

3- TR2 contained $800 \mathrm{~g}$ diet ( $21 \%$ protein $)+200 \mathrm{~g}$ fish powder $(65 \%$ protein $)+10 \mathrm{~g}$ black honey $+2 \mathrm{ml}$ Nigella sativa oil.

4-TR3 contained $800 \mathrm{~g}$ diet $(21 \%$ protein $)+200 \mathrm{~g}$ fish powder $(65 \%$ protein $)+10 \mathrm{~g}$ black honey $+3 \mathrm{ml}$ Nigella sativa oil.

Fish powder was imported from china. Biscuit machine was used to convert the mixture to granules with diameter $3 \mathrm{ml}$ and the drying was aerobic. Feed amounts were adjusted according to body weight and total number of fish / tank. Daily feed ration was calculated according to the following formula

DFR $=($ MBW $\times \mathbf{N} \times \mathbf{F R}) /$ day. (Nandlal and Pickering, 2004).

Where $\mathrm{DFR}=$ daily feed ration; $\mathrm{MBW}=$ mean body weight; $\mathrm{N}=$ number of the fish and $\mathrm{FR}=$ feeding rate. 


\section{Proximate analysis for tested diets:}

Chemical composition of experimental diets fed to Nile tilapia (Oreochromis niloticus) was recorded in Table 1. The tested diet for each treatment was chemically analyzed for protein, moisture, fat and ash according to standard methods of AOAC (1990). Crude fiber was determined according to Goering and Soest (1970).

Table 1. Chemical composition ( $\%$ as feed) of experimental diets fed to Nile tilapia (Oreochromis niloticus).

\begin{tabular}{lcccccc}
\hline \multicolumn{2}{l}{ Treatments Moisture Protein } & Fat & Fiber & \multicolumn{2}{c}{ Ash Carbohydrates } \\
\hline Control & 10.73 & 30.5 & 13.95 & 3.17 & 7.17 & 34.49 \\
TR1 & 10.14 & 30.54 & 13.94 & 2.61 & 8.12 & 34.65 \\
TR2 & 10.29 & 30.23 & 14.3 & 3.08 & 7.91 & 34.2 \\
TR3 & 10.36 & 29.98 & 14.78 & 2.87 & 8.31 & 33.72 \\
\hline
\end{tabular}

\section{Fish performance:}

Body weight, body length and body depth were taken every 15 day. Specific growth rate was described according to Sveier et al. (2000), while condition factor was calculated according to Eyo and Ekanem (2011) as following:

Specific growth rate $($ SGR, \% / day $)=(\log W 2-\log W 1 / T 2-T 1) \times 100$. Condition factor $=\left\{\left(\mathrm{W} / \mathrm{L}^{3}\right) * 100\right\}$

Where: $\mathrm{W} 1=$ initial weight; $\mathrm{W} 2=$ final weight; $\mathrm{T} 1=$ begin of experiment (day); $T 2=$ end of experiment (day); $W=$ mean body weight $(\mathrm{g}) ; \mathbf{L}=$ Mean standard length $(\mathrm{cm})$.

Feed intake (FI) is the total feed consumed (g) during experimental period.

Feed conversion ratio $($ FCR $)=$ FI / WG.

\section{Statistical analysis:}

The obtained data were statistically analyzed according to PROC ANOVA using the Statistical Analysis System (SAS, 2012) to test the effect of different treatments on body weight, body length, body depth, specific growth rate, condition factor, feed consumed, feed intake and feed conversion ratio. The differences between means were detected by Duncan's Multiple Range Test (Duncan, 1955).

Three non linear growth functions and linear regression model had been used to describe the changes in growth curve with time under the effect of adding different levels from Nigella sativa oil in tilapia diets. The mathematical relations of these equations are:

Von Bertalanffy: Wt=A (1-exp (-k (t- I)). Weibull: $W t=A-(A-B) \exp (-(k t) \delta)$.

Morgan-Mercer-Flodin: $\mathbf{W t}=\mathbf{A}-((\mathbf{A}-\mathrm{B}) /(\mathbf{1}+(\mathbf{k t}) \boldsymbol{\delta}))$.

Where: Wt is the live body weight at time $t$ of tilapia fish; $k$ is the rate of maturing; $A$ is the asymptotic weight when age approaches infinity; $\mathrm{l}$ is the ordinate of the inflection point; $B$ is the lower asymptote and $\delta$ is the parameter that controls the point of inflection.

\section{RESULTS AND DISCUSSION}

\section{Body weights:}

As presented in Table 2, adding different levels from Nigella sativa oil in Tilapia rations had significant effect on the different body weights, except initial body weight and body weight after 2 weeks. Higher level from Nigella sativa oil ( $3 \mathrm{ml}$ ) coupled with higher body weight followed by the level of $2 \mathrm{ml}$ and $1 \mathrm{ml}$ may be due to its antimicrobial effect and the abundance of essential amino acids which satisfy fish requirements as reported by Amal (1997).The difference between control diet and diet with $1 \mathrm{ml}$ Nigella sativa oil was not significant $(\mathrm{P}>0.05)$ for all body weights except after 6 and 8 weeks that showed significant differences $(\mathrm{P} \leq 0.05)$ in favor of diet with $1 \mathrm{ml}$ Nigella sativa oil. Body weights after 18, 20 and 22 weeks on diets with $2 \mathrm{ml}$ and $3 \mathrm{ml}$ Nigella sativa oil; after 20 and 22 weeks in diets with $1 \mathrm{ml}$ Nigella sativa oil and after 22 weeks in control diet decreased compared to the previous weights in sorting may be due to over-wintering regimes.

Table 2. Means \pm SE for body weights (g/fish) in Nile tilapia (Oreochromis niloticus).

\begin{tabular}{|c|c|c|c|c|c|}
\hline Weaks & Control & TR1 & TR2 & TR3 & P-Value \\
\hline Initial & $19.985 \pm 1.267$ & $18.836 \pm 1.602$ & $19.544 \pm 1.328$ & $20.824 \pm 1.247$ & 0.774 \\
\hline W 2 & $24.194 \pm 1.628$ & $23.113 \pm 1.987$ & $23.774 \pm 1.546$ & $24.908 \pm 1.469$ & 0.807 \\
\hline W 4 & $26.517 \pm 1.613^{b}$ & $30.469 \pm 2.299^{\mathrm{ab}}$ & $29.245 \pm 1.570^{\mathrm{ab}}$ & $33.695^{\mathrm{a}} \pm 1.671^{\mathrm{a}}$ & 0.049 \\
\hline W 6 & $29.609 \pm 1.863^{c}$ & $36.377 \pm 2.578^{b}$ & $35.447 \pm 1.665^{\mathrm{cb}}$ & $43.320^{\mathrm{a}} \pm 2.344^{\mathrm{a}}$ & 0.0003 \\
\hline W 8 & $35.560 \pm 2.143^{c}$ & $45.245 \pm 3.025^{\mathrm{b}}$ & $43.138 \pm 2.117^{b}$ & $55.485^{\mathrm{a}} \pm 2.505^{\mathrm{a}}$ & $<.0001$ \\
\hline W 10 & $43.517 \pm 2.613^{c}$ & $50.615 \pm 3.381^{\mathrm{cb}}$ & $57.750 \pm 2.510^{\mathrm{b}}$ & $66.592^{\mathrm{a}} \pm 2.881^{\mathrm{a}}$ & $<.0001$ \\
\hline W 12 & $51.916 \pm 2.738^{\mathrm{b}}$ & $53.694 \pm 3.471^{\mathrm{b}}$ & $72.344 \pm 3.027^{\mathrm{a}}$ & $71.035^{\mathrm{a}} \pm 2.212^{\mathrm{a}}$ & $<.0001$ \\
\hline W 14 & $52.901 \pm 2.957^{b}$ & $57.070 \pm 3.923^{\mathrm{b}}$ & $72.684 \pm 3.258^{\mathrm{a}}$ & $73.997^{\mathrm{a}} \pm 3.209^{\mathrm{a}}$ & $<.0001$ \\
\hline W 16 & $53.954 \pm 3.039^{b}$ & $58.819 \pm 4.043^{\mathrm{b}}$ & $74.114 \pm 3.335^{\mathrm{a}}$ & $74.717^{\mathrm{a}} \pm 3.249^{\mathrm{a}}$ & $<.0001$ \\
\hline W 18 & $54.886 \pm 3.159^{b}$ & $59.922 \pm 4.144^{\mathrm{b}}$ & $72.081 \pm 3.257^{\mathrm{a}}$ & $74.265^{\mathrm{a}} \pm 3.177^{\mathrm{a}}$ & 0.0002 \\
\hline W 20 & $59.238 \pm 3.742^{b}$ & $59.106 \pm 5.117^{b}$ & $71.702 \pm 3.930^{\mathrm{a}}$ & $70.094^{\mathrm{ab}} \pm 3.297^{\mathrm{ab}}$ & 0.045 \\
\hline W 22 & $57.395 \pm 3.729^{c}$ & $58.738 \pm 5.132^{\mathrm{cb}}$ & $71.241 \pm 3.741^{\mathrm{a}}$ & $69.805^{\mathrm{ab}} \pm 3.091^{\mathrm{ab}}$ & 0.0248 \\
\hline
\end{tabular}

a-c: means within a row not followed by the same letter differ significantly at $P \leq 0.05$.

The present results correspond with Abdelwahab and El-Bahr (2012) as they found significant influence of Black cumin seed and Turmeric mixture on body weight gain in Asian sea bass. Also, Qatnan and Al-Owafeir (2014) showed significant differences in final weights for Nile tilapia under the effect of different levels from Nigella sativa $(0,5,10$ and $20 \mathrm{~g} / \mathrm{kg})$. Concerning other medical oils and its effects on body weights in freshwater fish, Ayisi et al. (2017) obtained significant effect for palm oil on growth performance of Nile Tilapia. Sonmez et al. (2015) reported significant differences in final body weight between control diet and the diets with different levels from sage oils $(0.5,1$ and $1.5 \%)$ in rainbow trout fingerlings. Regarding medical herbs, Dias (2002) and Metwally (2009) reported that using of garlic resulted in improving the growth performance of Oreochromis niloticus fingerlings and Tilapia nilotica, respectively.

\section{Specific growth rate:}

Results in Table 3 revealed that all specific growth rate estimates was not significantly affected by adding different level from Nigella sativa oil $(\mathrm{P}>0.05)$, except specific growth rate between 8 and 10 weeks $(\mathrm{P}=0.050)$ 
what in accordance with the statements of Al-Dubakel et al. (2012), they found non significant differences in specific growth rate under the effect of different levels from Nigella sativa oil $(0,1$ and $3 \%)$ in a study conducted on common carp (Cyprinus carpio) fingerlings. In contrast;
Abdelwahab and El-Bahr (2012) in a study conducted on Asian sea bass found significant differences in specific growth rate $(\mathrm{P} \leq 0.05)$ with increasing the levels of Black cumin seed (Nigella sativa) and Turmeric mixture in fish diets being at range from $1.77 \%$ to $1.93 \%$.

Table 3. Means \pm SE for specific growth rate (SGR, \%/day) in Nile tilapia (Oreochromis niloticus).

\begin{tabular}{lccccc}
\hline Intervals & Control & TR1 & TR2 & TR3 & P-Value \\
\hline $0-2 \mathrm{~W}$ & $0.610 \pm 0.309$ & $0.676 \pm 0.212$ & $0.611 \pm 0.254$ & $0.651 \pm 0.227$ & 0.997 \\
$2-4 \mathrm{~W}$ & $0.980 \pm 0.293$ & $0.976 \pm 0.201$ & $0.806 \pm 0.234$ & $1.014 \pm 0.232$ & 0.237 \\
$4-6 \mathrm{~W}$ & $0.638 \pm 0.214$ & $0.620 \pm 0.326$ & $0.659 \pm 0.203$ & $0.794 \pm 0.231$ & 0.621 \\
$6-8 \mathrm{~W}$ & $0.620 \pm 0.190$ & $0.752 \pm 0.325$ & $0.650 \pm 0.235$ & $0.890 \pm 0.170$ & 0.853 \\
$8-10 \mathrm{~W}$ & $0.680^{\mathrm{ab}} \pm 0.163$ & $0.371^{\mathrm{b}} \pm 0.223$ & $0.998^{\mathrm{a}} \pm 0.150$ & $0.615^{\mathrm{ab}} \pm 0.138$ & 0.050 \\
$10-12 \mathrm{~W}$ & $0.641 \pm 0.269$ & $0.187 \pm 0.276$ & $0.761 \pm 0.128$ & $0.292 \pm 0.203$ & 0.231 \\
$12-14 \mathrm{~W}$ & $0.076 \pm 0.211$ & $0.099 \pm 0.261$ & $0.122 \pm 0.154$ & $0.078 \pm 0.206$ & 0.964 \\
$14-16 \mathrm{~W}$ & $0.062 \pm 0.267$ & $0.098 \pm 0.244$ & $0.062 \pm 0.120$ & $0.034 \pm 0.110$ & 0.996 \\
$16-18 \mathrm{~W}$ & $0.053 \pm 0.200$ & $0.058 \pm 0.266$ & $-0.092 \pm 0.152$ & $-0.018 \pm 0.149$ & 0.942 \\
$18-20 \mathrm{~W}$ & $0.035 \pm 0.359$ & $-0.456 \pm 0.420$ & $-0.115 \pm 0.278$ & $-0.441 \pm 0.188$ & 0.637 \\
$20-22 \mathrm{~W}$ & $-0.111 \pm 0.254$ & $-0.018 \pm 0.161$ & $-0.007 \pm 0.188$ & $-0.004 \pm 0.179$ & 0.977 \\
\hline
\end{tabular}

a-b: means within a row not followed by the same letter differ significantly at $P \leq 0.05$.

Higher specific growth rates were in primary ages of fish due to the good response to feeding in this period. Fish fed diets with 2 and $3 \mathrm{ml}$ Nigella sativa oil decreased in weight during winter experimental faster than those fed diets with $1 \mathrm{ml}$ Nigella sativa oil and control diet as negative signs were showed with the last three estimates for the diets with $2 \mathrm{ml}$ and $3 \mathrm{ml}$ Nigella sativa oil and with last two estimates for the diet with $1 \mathrm{ml}$ Nigella sativa oil and with the final estimate in control treatment as a consequence of feeding behavior in fish during winter season. Khattab (2001) reported that the highest estimate of average specific growth rate was recorded in group reared on diets with $10 \%$ black seed cake (Nigella sativa). Regarding other medical herbs and oils, Sahu et al. (2008) reported significant increase in specific growth rate in Labeo rohita fingerlings fed diets contained four levels from turmeric $(0.1,0.5,1.0$ and $5 \mathrm{~g})$. Altundag et al (2014) reported significant differences in specific growth rate in favor of diets contained sun flower oil ( $0.65 \%)$ compared to diets contained fish oil $(0.58 \%)$ in a study on turbot (Psetta maxima).

\section{Condition factor:}

Results in Table 4 clearly demonstrated that adding different doses from Nigella sativa oil had no significant effect on condition factor, except initial condition factor and after 12, 14, 16 and 22 weeks . Concerning other medical oils, Ayisi et al. (2017) used four levels from palm oil $(0,2 \%, 4 \%, 6 \%$ and $8 \%)$ and did not find significant differences in condition factor in different treatments $(1.88$, 1.92, 2.00, 2.00, and 1.87, respectively). Also, Diler et al. (2017) did not record significant differences in condition factor in a study on oregano (Origanum onites L.) in rainbow trout $(1.24,1.25,1.23,1.23$ and 1.24 for control, $0.125 \mathrm{ml} \mathrm{kg}-1,1.5 \mathrm{ml} \mathrm{kg}-1,2.5 \mathrm{ml} \mathrm{kg}-1$ and $3.0 \mathrm{ml} \mathrm{kg}-1$, respectively).

Table 4. Means \pm SE for condition factor (CF) in Nile tilapia (Oreochromis niloticus).

\begin{tabular}{lccccc}
\hline Intervals & Control & T1 & T2 & T3 & P-Value \\
\hline Initial & $1.724 \pm 0.035^{\mathrm{ab}}$ & $1.738 \pm 0.025^{\mathrm{ab}}$ & $1.939 \pm 0.146^{\mathrm{a}}$ & $1.642 \pm 0.018^{\mathrm{b}}$ & 0.048 \\
W 2 & $1.700 \pm 0.024$ & $1.739 \pm 0.029$ & $1.751 \pm 0.033$ & $1.744 \pm 0.019$ & 0.547 \\
W 4 & $1.633 \pm 0.026$ & $1.668 \pm 0.027$ & $1.600 \pm 0.041$ & $1.649 \pm 0.018$ & 0.420 \\
W 6 & $1.659 \pm 0.016$ & $1.676 \pm 0.015$ & $1.693 \pm 0.018$ & $1.737 \pm 0.123$ & 0.841 \\
W 8 & $1.635 \pm 0.012$ & $1.598 \pm 0.019$ & $1.605 \pm 0.024$ & $1.612 \pm 0.017$ & 0.540 \\
W 10 & $1.634 \pm 0.019$ & $1.595 \pm 0.021$ & $1.552 \pm 0.055$ & $1.601 \pm 0.016$ & 0.359 \\
W 12 & $1.680 \pm 0.013^{\mathrm{b}}$ & $1.607 \pm 0.025^{\mathrm{c}}$ & $1.789 \pm 0.027^{\mathrm{a}}$ & $1.646 \pm 0.017^{\mathrm{bc}}$ & $<.0001$ \\
W 14 & $1.592 \pm 0.017^{\mathrm{b}}$ & $1.595 \pm 0.019^{\mathrm{b}}$ & $1.680 \pm 0.020^{\mathrm{a}}$ & $1.623 \pm 0.019^{\mathrm{b}}$ & 0.004 \\
W 16 & $1.610 \pm 0.018^{\mathrm{b}}$ & $1.631 \pm 0.031^{\mathrm{ab}}$ & $1.700 \pm 0.023^{\mathrm{a}}$ & $1.635 \pm 0.020^{\mathrm{ab}}$ & 0.051 \\
W 18 & $1.590 \pm 0.017$ & $1.571 \pm 0.017$ & $1.608 \pm 0.024$ & $1.568 \pm 0.057$ & 0.810 \\
W 20 & $1.574 \pm 0.021$ & $1.527 \pm 0.017$ & $1.862 \pm 0.246$ & $1.540 \pm 0.016$ & 0.186 \\
W 22 & $1.523 \pm 0.028^{\mathrm{ab}}$ & $1.473 \pm 0.020^{\mathrm{b}}$ & $1.589 \pm 0.030^{\mathrm{a}}$ & $1.521 \pm 0.024^{\mathrm{ab}}$ & 0.024 \\
\hline $\mathrm{a}$ & & & & &
\end{tabular}

a-c: means within a row not followed by the same letter differ significantly at $P \leq 0.05$.

\section{Body length:}

The effects of elevated dietary Nigella sativa oil levels on all body length estimates were significant during experimental trail, except initial body length and after 2, 10 and 20 weeks. Non significant differences $(\mathrm{P}>0.05)$ were showed between control diets and diets with $1 \mathrm{ml}$ Nigella sativa oil except after 6 and 8 week showed significant differences $(\mathrm{P} \leq 0.05)$ in favor of diet with $1 \mathrm{ml}$ Nigella sativa oil (Table 5). Regarding medical herbs, Nwabueze (2012) used different concentration from garlic and showed a slight differences in body length of Clarias gariepinus fingerlings but did not differ significantly $(\mathrm{P}>0.05)$. 
Table 5. Means \pm SE for total body length (cm) in Nile tilapia (Oreochromis niloticus).

\begin{tabular}{lccccc}
\hline Intervals & Control & T1 & T2 & T3 & P-Value \\
\hline Initial & $10.363 \pm 0.218$ & $10.050 \pm 0.272$ & $10.070 \pm 0.281$ & $10.713 \pm 0.234$ & 0.279 \\
W 2 & $11.073 \pm 0.265$ & $10.760 \pm 0.298$ & $10.965 \pm 0.287$ & $11.138 \pm 0.231$ & 0.681 \\
W 4 & $11.613 \pm 0.207^{\mathrm{b}}$ & $12.000 \pm 0.299^{\mathrm{ab}}$ & $12.136 \pm 0.298^{\mathrm{ab}}$ & $12.590 \pm 0.202^{\mathrm{a}}$ & 0.031 \\
W 6 & $11.963 \pm 0.251^{\mathrm{c}}$ & $12.726 \pm 0.299^{\mathrm{b}}$ & $12.700 \pm 0.217^{\mathrm{b}}$ & $13.606 \pm 0.233^{\mathrm{a}}$ & 0.0002 \\
W 8 & $12.786 \pm 0.265^{\mathrm{c}}$ & $13.936 \pm 0.320^{\mathrm{b}}$ & $13.806 \pm 0.235^{\mathrm{b}}$ & $14.996 \pm 0.244^{\mathrm{a}}$ & $<.0001$ \\
W 10 & $13.683 \pm 0.271$ & $14.466 \pm 0.319$ & $13.266 \pm 0.445$ & $14.980 \pm 0.227$ & 0.216 \\
W 12 & $14.407 \pm 0.259^{\mathrm{b}}$ & $14.789 \pm 0.339^{\mathrm{b}}$ & $15.825 \pm 0.234^{\mathrm{a}}$ & $16.196 \pm 0.582^{\mathrm{a}}$ & $<.0001$ \\
W 14 & $14.764 \pm 0.282^{\mathrm{b}}$ & $15.050 \pm 0.358^{\mathrm{b}}$ & $16.196 \pm 0.238^{\mathrm{a}}$ & $16.489 \pm 0.265^{\mathrm{a}}$ & $<.0001$ \\
W 16 & $14.810 \pm 0.295^{\mathrm{b}}$ & $15.085 \pm 0.339^{\mathrm{b}}$ & $16.239 \pm 0.245^{\mathrm{a}}$ & $16.507 \pm 0.265^{\mathrm{a}}$ & $<.0001$ \\
W 18 & $14.939 \pm 0.279^{\mathrm{b}}$ & $15.371 \pm 0.377^{\mathrm{b}}$ & $16.403 \pm 0.262^{\mathrm{a}}$ & $16.621 \pm 0.527^{\mathrm{a}}$ & 0.0002 \\
W 20 & $15.390 \pm 0.356$ & $15.386 \pm 0.463$ & $16.000 \pm 0.373$ & $16.481 \pm 0.266$ & 0.115 \\
W 22 & $15.409 \pm 0.376^{\mathrm{b}}$ & $15.545 \pm 0.464^{\mathrm{ab}}$ & $16.400 \pm 0.265^{\mathrm{ab}}$ & $16.559 \pm 0.285^{\mathrm{a}}$ & 0.051 \\
\hline
\end{tabular}

a-c: means within a row not followed by the same letter differ significantly at $P \leq 0.05$.

\section{Body depth:}

As showed in Table 6, adding different levels from Nigella sativa oil in tilapia diets had significant effect $(\mathrm{P} \leq 0.001)$ on all estimates except initial body depth and after 2 and 20 weeks. Higher level from Nigella sativa oil $(3 \mathrm{ml})$ coupled with higher body length followed by the level of $2 \mathrm{ml}$ and $1 \mathrm{ml}$.

Table 6. Means \pm SE for body depth (cm) in Nile tilapia (Oreochromis niloticus).

\begin{tabular}{lccccc}
\hline Intervals & Control & T1 & T2 & T3 & P-Value \\
\hline Initial & $3.353 \pm 0.075$ & $3.086 \pm 0.099$ & $3.253 \pm 0.083$ & $3.200 \pm 0.078$ & 0.166 \\
W 2 & $3.493 \pm 0.099$ & $3.250 \pm 0.098$ & $3.406 \pm 0.083$ & $3.438 \pm 0.070$ & 0.230 \\
W 4 & $3.433 \pm 0.096^{\mathrm{b}}$ & $3.630 \pm 0.100^{\mathrm{ab}}$ & $3.590 \pm 0.073^{\mathrm{b}}$ & $3.866 \pm 0.064^{\mathrm{a}}$ & 0.005 \\
W 6 & $3.536 \pm 0.091^{\mathrm{c}}$ & $3.606 \pm 0.099^{\mathrm{c}}$ & $3.886 \pm 0.074^{\mathrm{b}}$ & $4.340 \pm 0.092^{\mathrm{a}}$ & $<.0001$ \\
W 8 & $3.753 \pm 0.098^{\mathrm{c}}$ & $4.096 \pm 0.112^{\mathrm{b}}$ & $4.133 \pm 0.078^{\mathrm{ab}}$ & $4.386 \pm 0.091^{\mathrm{a}}$ & $<.0001$ \\
W 10 & $4.116 \pm 0.092^{\mathrm{b}}$ & $4.276 \pm 0.108^{\mathrm{b}}$ & $4.396 \pm 0.086^{\mathrm{b}}$ & $4.680 \pm 0.101^{\mathrm{a}}$ & 0.0008 \\
W 12 & $4.364 \pm 0.101^{\mathrm{b}}$ & $4.353 \pm 0.114^{\mathrm{b}}$ & $4.785 \pm 0.122^{\mathrm{a}}$ & $4.685 \pm 0.110^{\mathrm{ab}}$ & 0.016 \\
W 14 & $4.335 \pm 0.105^{\mathrm{b}}$ & $4.457 \pm 0.132^{\mathrm{b}}$ & $5.000 \pm 0.088^{\mathrm{a}}$ & $4.975 \pm 0.092^{\mathrm{a}}$ & $<.0001$ \\
W 16 & $4.496 \pm 0.112^{\mathrm{b}}$ & $4.582 \pm 0.120^{\mathrm{b}}$ & $5.164 \pm 0.094^{\mathrm{a}}$ & $5.117 \pm 0.084^{\mathrm{a}}$ & $<.0001$ \\
W 18 & $4.503 \pm 0.116^{\mathrm{b}}$ & $4.510 \pm 0.147^{\mathrm{b}}$ & $4.946 \pm 0.104^{\mathrm{a}}$ & $4.857 \pm 0.103^{\mathrm{a}}$ & 0.013 \\
W 20 & $4.572 \pm 0.130$ & $4.413 \pm 0.163$ & $4.818 \pm 0.124$ & $4.781 \pm 0.110$ & 0.119 \\
W 22 & $4.063 \pm 0.126^{\mathrm{b}}$ & $4.172 \pm 0.163^{\mathrm{b}}$ & $4.900 \pm 0.096^{\mathrm{a}}$ & $4.659 \pm 0.100^{\mathrm{a}}$ & $<.0001$ \\
\hline $\mathrm{a}$ & & & & &
\end{tabular}

a-c: means within a row not followed by the same letter differ significantly at $P \leq \mathbf{0 . 0 5}$.

The differences between control diet and diet with $1 \mathrm{ml}$ Nigella sativa oil were not significant $(\mathrm{P}>0.05)$ for all body depth estimates, except after 8 weeks showed significant differences $(\mathrm{P} \leq 0.05)$ in favor of diet with $1 \mathrm{ml}$ Nigella sativa oil. The loses in body depth during winter period were on line with that observed in body weight [Last three estimates in diet with $2 \mathrm{ml}$ and $3 \mathrm{ml}$ Nigella sativa oil; last two estimates in diet with $1 \mathrm{ml}$ Nigella sativa oil and last estimate in control diet] may be due to the losses in belly fat.

\section{Feed utilization:}

It is clearly appears that feed intake (Table 7) increased with increasing the level of Nigella sativa oil in tested diets. With regard to feed conversion ratio, significant differences were showed between all tested diets, being at range from $1.670 \pm 0.041$ for control diet to $2.153 \pm 0.084$ in ration with $3 \mathrm{ml}$ Nigella sativa oil.

Table 7. Means \pm SE for feed intake (FI, g/fish) and feed conversion ratio (FCR) throughout the experiment.

\begin{tabular}{lccccc}
\hline Items & Control & T1 & T2 & T3 & P-Value \\
\hline FI & $97.216 \pm 4.09^{\mathrm{c}}$ & $108.427 \pm 5.437^{\mathrm{cb}}$ & $117.966 \pm 3.73^{\mathrm{b}}$ & $133.557 \pm 4.285^{\mathrm{a}}$ & $<.0001$ \\
FCR & $1.670 \pm 0.041^{\mathrm{b}}$ & $1.921 \pm 0.094^{\mathrm{a}}$ & $1.969 \pm 0.092^{\mathrm{a}}$ & $2.153 \pm 0.084^{\mathrm{a}}$ & 0.0008 \\
\hline
\end{tabular}

a-c: means within a row not followed by the same letter differ significantly at $P \leq 0.05$.

The present results comply with Qatnan and AlOwafeir (2014), they found significant differences in feed conversion ratio for tilapia fish, being at range from 1.12 to 3.73 under the effect of different levels from black seed meal. Contradictory results were showed by Khattab (2001) who found non significant differences in feed conversion ratio for tilapia fish under the effect of adding black seed meal in tested diets, also Abdelwahab and El-Bahr (2012) came to same conclusion in a study on Asian sea bass.

\section{Growth curve:}

Different non linear functions were used to describe growth curve in the present study such as Von Bertalanffy model, Weibull model and Morgan-Mercer-Flodin model in addition to linear model. Different authors in different studies reported that non linear models gave highest accuracies in the description of growth curve (Esenbuğa et al., 2000; Lewis et al., 2002; Bilgin and Esenbuga, 2003; Topal et al., 2004; Tekel et al, 2005;Tariq et al., 2013 and Sieklicki et al., 2016).

Results in Table 8 showed the different parameters along with their standard error for different growth models fitted to body weight in Nile tilapia (Oreochromis niloticus) reared on diets with different levels from Nigella sativa oil. Sieklicki et al. (2016) reported that the knowledge of the 
different parameters for non linear models is very important to establish specific feeding managements and determine the marketing age.

Concerning control treatment, $\mathrm{K}$ parameter which shows the maturating rate was at range $0.0073 \pm 0.003$ (Von Bertalanffy) to $0.0157 \pm 0.001$ (Morgan-Mercer-Flodin), while $l$ parameter which shows the ordinate of the inflection point was $-31.415 \pm 11.466$ (Von Bertalanffy model). Highest value of A parameter $(81.3257 \pm 17.168)$ was showed with Von Bertalanffy model followed by $59.7215 \pm 2.2657$ with Morgan-Mercer-Flodin model and 57.3579 \pm 1.2801 with Weibull model.the $\sigma$ parameter estimates were $2.4083 \pm 0.365$ and $3.4269 \pm 0.6613$ for Weibull model and Mercer-Flodin model, respectively like A parameter estimates has no biological interpretation, while $\beta$ parameters estimates were $21.6443 \pm 1.3941$ and $22.4347 \pm 1.3393$ for Weibull model and Mercer-Flodin model, respectively. Linear regression equation was incorporated as

\section{$\mathrm{W}=20.9902+0.27831 * t$.}

Regarding tested diet with $1 \mathrm{ml}$ Nigella sativa oil, A parameters along with their standard errors were $66.8631 \pm 3.536 \pm 0.540,59.733 \pm 0.540$ and $63.0340 \pm 1.6187$ for Von Bertalanffy, Weibull and Morgan-Mercer-Flodin, respectively, while $\mathrm{K}$ parameters were $0.0150 \pm 0.002$, $0.0178 \pm 0.001$ and $0.0208 \pm 0.001$ for the same order mentioned before. The $l$ parameter was $-17.246 \pm 4.416$ (Von Bertalanffy). The $\sigma$ parameters were $1.7341 \pm 0.102$ and $2.3349 \pm 0.267$, while $\beta$ parameters were $19.2198 \pm 0.719$ and
$19.8276 \pm 1.0687$ for Weibull model and Morgan-MercerFlodin model, respectively. Linear regression equation was formulated as

\section{$\mathrm{W}=\mathbf{2 4 . 3 9 9 2 5 + 0 . 2 8 0 2 3 * t .}$}

In connection to tested diet with $2 \mathrm{ml}$ Nigella sativa oil, A parameter was at range from $72.8906 \pm 1.3009$ (Weibull model) to $90.7900 \pm 15.8147$ (Von Bertalanffy model), while $\mathrm{K}$ parameter was at range from $0.0115 \pm 0.005$ (Von Bertalanffy model) to $0.0171 \pm 0.001$ (Morgan-MercerFlodin model). The $l$ parameter had a negative sign ($13.2211 \pm 9.1931)$ for Von Bertalanffy model. The $\sigma$ parameter was $3.4190 \pm 0.5558$ and $5.1267 \pm 1.2291$ while $\beta$ parameters were $23.1895 \pm 1.8252$ and $24.2225 \pm 2.2484$ for Weibull model and Morgan-Mercer-Flodin model, respectively. Linear regression was designed as $\mathrm{W}=22.78007+0.39968 * \mathrm{t}$. Regarding test ration with $3 \mathrm{ml}$ Nigella sativa oil, the values of A parameter were $80.3951 \pm$ $6.2638,72.7904 \pm 0.9729$ and $74.1651 \pm 1.9073$, while the values of $\mathrm{K}$ parameter were $0.0178 \pm 0.004,0.0189 \pm 0.001$ and $0.0219 \pm 0.001$ for Von Bertalanffy, Weibull and Morgan-Mercer-Flodin models, respectively. The values of $\sigma$ and $\beta$ parameters were $2.4179 \pm 0.2963$ and $22.1651 \pm 1.6812$, respectively for Weibull equation; $3.6746 \pm 0.715$ and $23.3427 \pm 2.1743$, respectively for Morgan-Mercer-Flodin equation. The value of $l$ parameter was $-10.6172 \pm 5.8713$ for Von Bertalanffy equation. Linear regression equation was recorded as

$\mathrm{W}=28.66147+0.36195 * t$.

Table 8. Estimated parameters \pm SE for different growth models fitted to body weight in Nile tilapia (Oreochromis niloticus) reared on diets with different levels from Nigella sativa oil.

\begin{tabular}{|c|c|c|c|c|c|c|}
\hline \multirow{2}{*}{ Treatments } & \multirow{2}{*}{ Model } & \multicolumn{5}{|c|}{ Parameters } \\
\hline & & $A$ & $K$ & $l$ & $\sigma$ & $\beta$ \\
\hline \multirow{7}{*}{ Control } & & 81.3257 & 0.0073 & -31.514 & & \\
\hline & Von Bertalantty & \pm 17.168 & \pm 0.003 & \pm 11.466 & --- & --- \\
\hline & & 57.3579 & 0.0140 & & 2.4083 & 21.6443 \\
\hline & Weibull & \pm 1.2801 & \pm 0.001 & --- & \pm 0.365 & \pm 1.3941 \\
\hline & & 59.7215 & 0.0157 & & 3.4269 & 22.4347 \\
\hline & Morgan-Mercer-Flodin & \pm 2.2657 & \pm 0.001 & --- & \pm 0.6613 & \pm 1.3393 \\
\hline & Linear regression & \multicolumn{5}{|c|}{$\mathrm{W}=20.9902+0.27831 \mathrm{t}$} \\
\hline \multirow{7}{*}{ T1 (1ml Nigella sativa oil) } & Von Rertalanffy & 66.8631 & 0.0150 & -17.246 & & \\
\hline & Von Bertalaniry & \pm 3.536 & \pm 0.002 & \pm 4.416 & --- & --- \\
\hline & & 59.733 & 0.0178 & & 1.7341 & 19.2198 \\
\hline & Weibu & \pm 0.540 & \pm 0.001 & $\cdots$ & \pm 0.102 & \pm 0.719 \\
\hline & & 63.0340 & 0.0208 & & 2.3349 & 19.8276 \\
\hline & Morgan-Mercer-Flodın & \pm 1.6187 & \pm 0.001 & --- & \pm 0.267 & \pm 1.0687 \\
\hline & Linear regression & \multicolumn{5}{|c|}{$\mathrm{W}=24.39925+0.28023 \mathrm{t}$} \\
\hline \multirow{7}{*}{ T2 (2ml Nigella sativa oil) } & & 90.7900 & 0.0115 & -13.2211 & & \\
\hline & Von Bertalantfy & \pm 15.8147 & \pm 0.005 & \pm 9.1931 & - & --- \\
\hline & & 72.8906 & 0.0154 & & 3.4190 & 23.1895 \\
\hline & Weibull & \pm 1.3009 & \pm 0.001 & --- & \pm 0.5558 & \pm 1.8252 \\
\hline & Mororn_Mercer_Flodin & 74.1083 & 0.0171 & & 5.1267 & 24.2225 \\
\hline & Morgan-Mercer-Flodın & \pm 2.2551 & \pm 0.001 & --- & \pm 1.2291 & \pm 2.2484 \\
\hline & Linear regression & \multicolumn{5}{|c|}{$\mathrm{W}=22.78007+0.39968 \mathrm{t}$} \\
\hline \multirow{7}{*}{ T3 (3ml Nigella sativa oil) } & & 80.3951 & 0.0178 & -10.6172 & & \\
\hline & Von Bertalantty & \pm 6.2638 & \pm 0.004 & \pm 5.8713 & --- & --- \\
\hline & Weibull & 72.7904 & 0.0189 & --- & 2.4179 & 22.1651 \\
\hline & Weibull & \pm 0.9729 & \pm 0.001 & --- & \pm 0.2963 & \pm 1.6812 \\
\hline & & 74.1651 & 0.0219 & & 3.6746 & 23.3427 \\
\hline & Morgan-Mercer-Flodın & \pm 1.9073 & \pm 0.001 & --- & \pm 0.715 & \pm 2.1743 \\
\hline & Linear regression & \multicolumn{5}{|c|}{$\mathrm{W}=28.66147+0.36195 \mathrm{t}$} \\
\hline
\end{tabular}


Figures 1, 2, 3, 4, 5, 6, 7 and 8 show the fitted curves for Moran-Mercer-Flodin, Von Bertalanffy, and Linear and Weibull models against the observed values of body weight. From these figures it is evident that Weiblull growth curve followed by Moran-Mercer-Flodin curve and Von Bertalanffy curve predicted the values of body weight better than linear regression model in all experimental diets. Morgan-Mercer-Flodin and Weibull curves are the best curves as they took the optimum shape of biological growth curve which take $S$ shape as growth evolution from period to another is nonlinear compared to linear

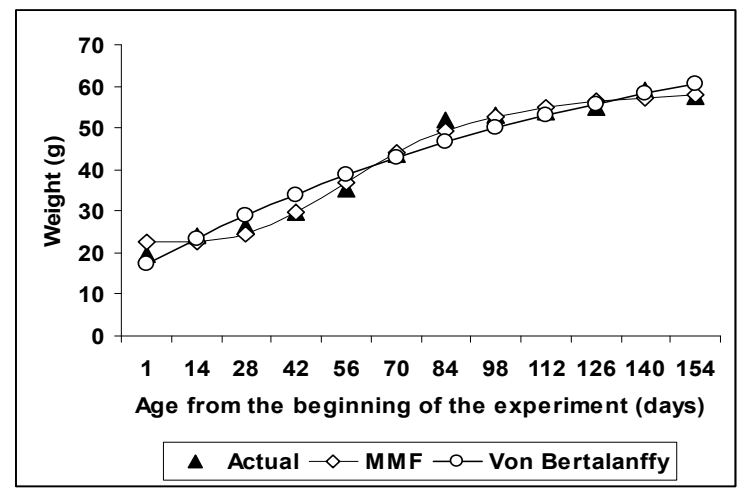

Fig. 1. Actual, Morgan-Mercer-Flodin (MMF) and Von Bertalanffy growth curve fitted to body weights for control diet.

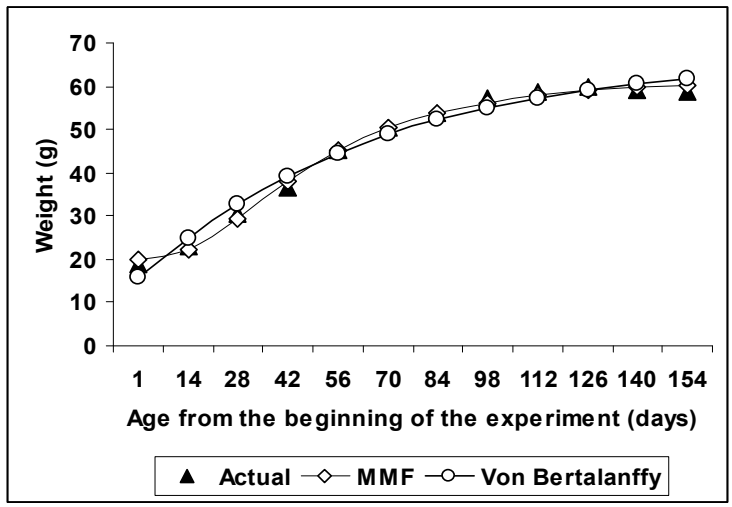

Fig. 3. Actual, Morgan-Mercer-Flodin (MMF) and Von Bertalanffy growth curve fitted to body weights for tested diet with $1 \mathrm{ml}$ Nigella sativa oil.

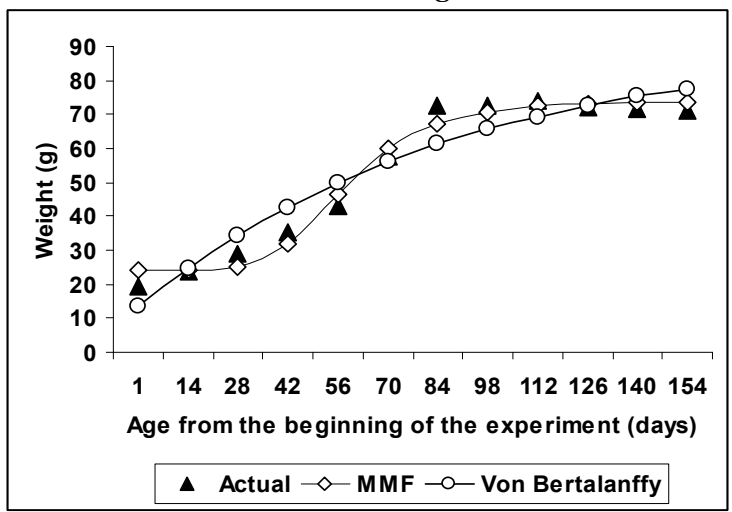

Fig. 5. Actual, Morgan-Mercer-Flodin (MMF) and Von Bertalanffy growth curve fitted to body weights for tested diet with $\mathbf{2} \mathrm{ml}$ Nigella sativa oil. regression curve that took line shape (Ibáñez-Escriche and Blasco, 2011). Fernanda et al. (2015) used non linear model (Gompertz) to describe the growth curve in males and females in Colossoma macropomum and showed that growth curve took $S$ shape in both sexes from the birth up to 1000 day and the equations were formulated as $\mathrm{W}=5010^{*} \operatorname{EXP}(-\operatorname{EXP}((-0.00507 *(\mathrm{t}-488))))$ and $\mathrm{W}=4641^{*}$ EXP (- EXP $((-0.00507 *(\mathrm{t}-474.7))))$ in females and males respectively. Maunder et al. (2017) reported that growth Cessation curve was better than Richards and Von Bertalanffy curves in bigeye tuna (Thunnus obesus).

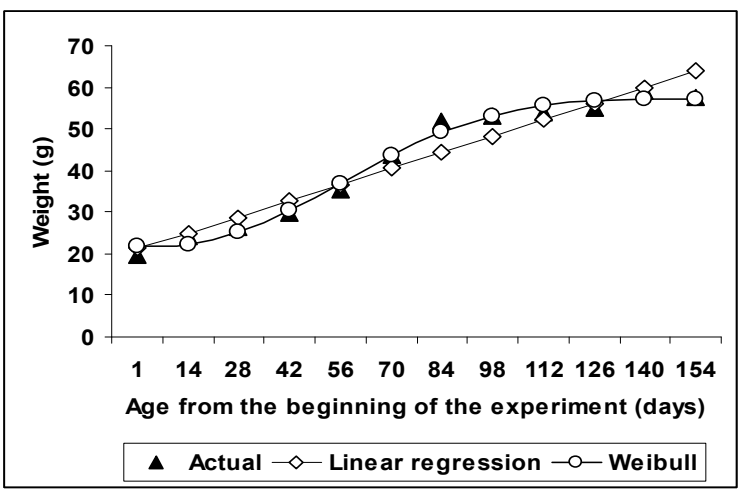

Fig. 2. Actual, linear regression and Weibull growth curve fitted to body weights for control diet.

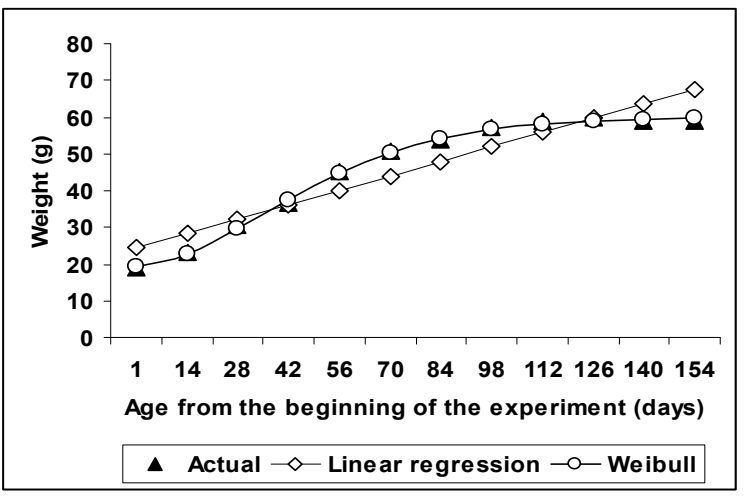

Fig. 4. Actual, linear regression and Weibull growth curve fitted to body weights for control diets for tested diet with $1 \mathrm{ml}$ Nigella sativa oil.

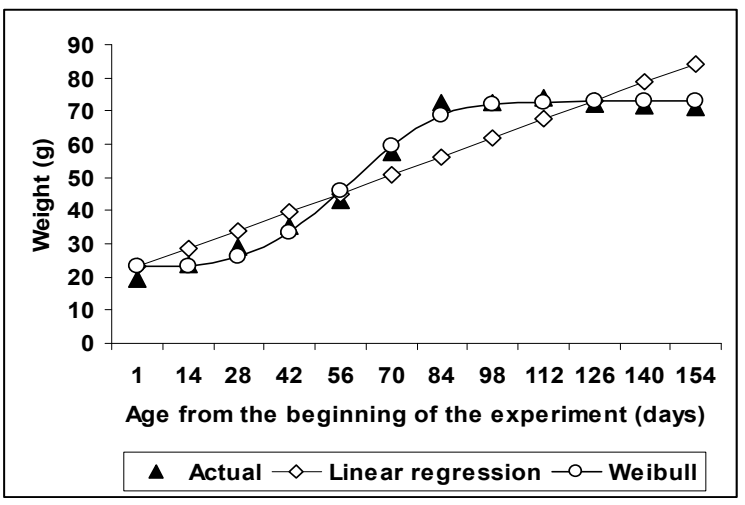

Fig. 6. Actual, linear regression and Weibull growth curve fitted to body weights for control diets for tested diet with $2 \mathrm{ml}$ Nigella sativa oil. 


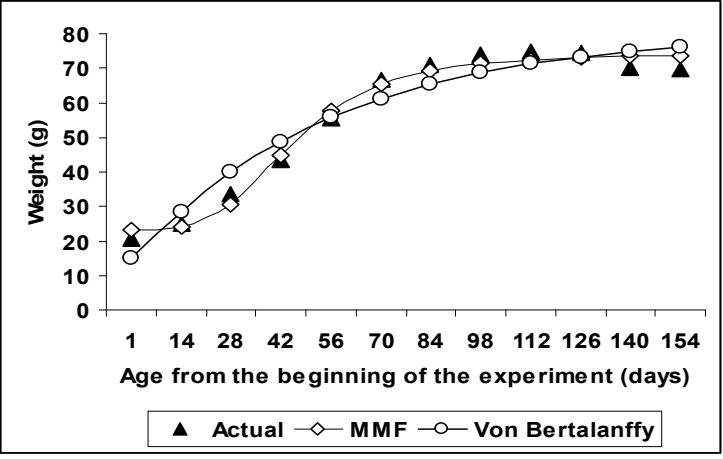

Fig. 7. Actual, Morgan-Mercer-Flodin (MMF) and Von Bertalanffy growth curve fitted to body weights for tested diet with $3 \mathrm{ml}$ Nigella sativa oil.

Results in Table 9 presented the goodness of fit measures for different growth models fitted to body weight in Nile tilapia (Oreochromis niloticus) reared on diets with different levels from Nigella sativa oil according to coefficient of determination and the mean standard errors. Weibull and Morgan-Mercer-Flodin models were the best equations to describe growth curve in Nile tilapia as they

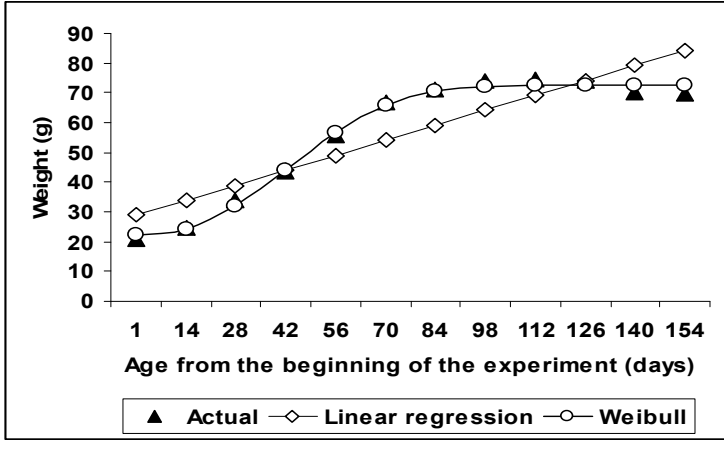

Fig. 8. Actual, linear regression and Weibull growth curve fitted to body weights for control diets for tested diet with $3 \mathrm{ml}$ Nigella sativa oil.

gave higher accuracies followed by Von Bertalanffy and linear regression. The present result agreed with Al- Anbari et al. (2013) who found that non linear models were higher in their accuracies in the description of growth curve than linear model as the mean standard error was 58463.46 for linear regression model and decreased to be 637.11 for weighted least square growth function.

Table 9. Goodness of fit measures for different growth models fitted to body weight in Nile tilapia (Oreochromis niloticus) reared on diets with different levels from Nigella sativa oil.

\begin{tabular}{lcccc}
\hline $\begin{array}{l}\text { Ages from the beginning of the } \\
\text { experiment (days) }\end{array}$ & MMF & $\begin{array}{c}\text { Von } \\
\text { Bertalanffy }\end{array}$ & $\begin{array}{c}\text { Linear } \\
\text { regression }\end{array}$ & Weibull \\
\hline Control: & 3.8540 & 10.069 & 15.325 & 3.6022 \\
MSE & 98.67 & 96.08 & 93.37 & 98.75 \\
$R^{2}(\%)$ & 1.5115 & 5.6890 & 30.2306 & 0.6400 \\
T1 (1ml Nigella sativa oil): & 99.51 & 97.94 & 87.87 & 99.79 \\
MSE & & & & \\
$R^{2}(\%)$ & 13.3921 & 45.8823 & 76.2735 & 7.5443 \\
T2 (2ml Nigella sativa oil): & 97.94 & 92.08 & 85.38 & 98.84 \\
MSE & & & & \\
$R^{2}(\%)$ & 8.6411 & 30.9931 & 94.23936 & 4.3389 \\
T3 (3ml Nigella sativa oil): & 98.49 & 93.93 & 79.49 & 99.24 \\
MSE & & $\mathrm{Al}$ & \\
$R^{2}(\%)$ &
\end{tabular}

\section{CONCLUSION}

The present results concluded that inclusion of Nigella sativa oil in Nile tilapia (Oreochromis niloticus) diets improved growth performance and feed utilization relatively at $3 \mathrm{ml}$ concentrate. For growth curve description under the effect of different treatments, Weibull and Morgan-Mercer-Flodin models were the best equations to describe growth curve in Nile tilapia followed by Von Bertalanffy and linear regression.

\section{REFERENCES}

Abdelwahab, A.M. and El-Bahr S.M. (2012). Influence of black cumin seeds (Nigella sativa) and turmeric (Curcuma longa Linn.) mixture on performance and serum biochemistry of Asian sea bass, Lates calcarifer. World Journal of Fish and Marine Sciences, 4 (5): 496-503.

Al- Anbari, E.H., Ahmed, A. A., Firas, R. A., Jenan, S. A. and Falah, H. A. (2013). Effect of using cumin oil (Cuminum cyminum) as feed additives on profile analysis and growth curve of broiler. G.J.B.B., 2 (3): 326-330.
Al-Dubakel, A.Y., Al-Mhawe, B.H., Majeed, M.F. and Shaeyal, L.W. (2012). Preliminary study on the effect of dietary black seed (Nigella sativa) on growth and blood glucose of common carp (Cyprinus carpio) fingerlings. J. of Thi_Qar Univ. for Agri. Researches, 1 (2): 41-51.

Altundag, M.S., Tiril, S.U. and Ozdemir, A. (2014). Effects of safflower oil supplementation in diet on growth performance and body fatty acid composition of turbot (Psetta maxima). Aquacult. Int., 22: 597-605.

Amal, F. (1997). Pharmacological studies on Nigella stavia L. on chickens infected with Salmonella typhimurium. M.V.Sc. (Pharmacology). Zagazig Univ., Egypt.

AOAC. (1990). Association of Official Analytical Chemists Official Methods of Analyses. $15^{\text {th }}$ Ed. In: K. Helrich Ed. Inc., Arlington, VA, USA. 
Ayisi, C.L., Jinliang Z. and Emmanuel, E.J. (2017). Growth performance, feed utilization, body and fatty acid composition of Nile tilapia (Oreochromis niloticus) fed diets containing elevated levels of palm oil. DOI: 10.1016/j.aaf.2017.02.001

Bilen, S., Bulut, M. and Bilen, M.A. (2011). Immunostimulant effects of Cotinus coggyria on rainbow trout (Oncorhynchus mykiss). Fish and Shellfish Immunology, 30 (2): 451-455.

Bilen, S., Y1lmaz, S. and Bilen, M.A. (2013). Influence of tetra (Cotinus coggygria) extract against Vibrio anguillarum infection in koi carp, Cyprinus carpio with reference to haematological and 1mmunological changes. Turk. J. Fish. Aquat. Sci., 13 (3): 527-532.

Bilen, S., Y1lmaz, S., Bilen, M.A. and Biswas, G. (2014). Effects of dietary incorporation of tetra (Cotinus coggygria) extract on immune response and resistance to Aeromonas hydrophila in koi Carp (Cyprinus carpio), 7 pages. The Israeli Journal of Aquaculture - Bamidgeh, 66: 1-6.

Bilgin, O.C. and Esenbuga, N. (2003). Parameter estimation in nonlinear growth models. J. Anim. Prod., 44: 81-90.

Dias, A.S., El-Nagar, G.O. and El-Hady, Y. M. (2002). Evaluation of Nigella sativa (black seed, baraka), Allium sativum (garlic) and BIOGEN as feed additives on growth performance and immunostimulants of Oreochromis niloticus fingerlings. Suez Canal Veterinary medical Journal, $1 ; 745-750$.

Diler, O.; Gormez, O.; Diler, I. and Metin, S. (2017). Effect of oregano (Origanum onites L.) essential oil on growth, lysozyme and antioxidant activity and resistance against Lactococcus garvieae in rainbow trout, Oncorhynchus mykiss (Walbaum). Agriculture Nutrition, 23: 844-851.

Duncan, D. B. (1955). Multiple range and multiple F-test. Biometrics, 11: 1- 24 .

El-Sayed, A. F. M. (200). Tilapia culture. CABI publishing, oxfordshire fatty acid metabolism. Journal of Nutrition, 132: 222-230.

Esenbuğa, N.; Bilgin, Ö.C.; Macit, M. and Karaoğlu, M. (2000). Growth curves in Awassi, Morkaraman and Tushin lambs. Atatürk Univ. The J. Agric. Fac., 31: 37-41.

Eyo, V.O and Ekanem, A. (2011). Effect of feeding frequency on the growth, food utilization and survival of African catfish (Clarias gariepinus) using locally formulated diet. Afr. J. Environ. Pollut. Health, 9: 11-16.

Fernanda, M.; Carlos, A.L.; Ricardo, P.; Emiko, K.; Resende, J.; Povh, D.; Rogério, V.; Concepta, M. and Danilo, S. (2015). Growth curve by Gompertz nonlinear regression model in females and males in tambaqui (Colossoma macropomum). Anais da Academia Brasileira de Ciências, 87 (4): 23092315.

Goering, H.K. and Soest, P.G.V. (1970). Forage Fiber Analysis (apparatus, reagent, procedures, and some applications). US Dept. Agric. Handbook, Washington, D.C., USA, 379.
Ibáñez-Escrich, E N and Blasco, A. (2011). Modifying growth curve parameters by multitrait genomic selection. J. Anim. Sci., 89: 661-668.

Kapoor,L.D. (1990). Handbook of ayurvedic medicinal plants. CRC. press, Inc., Boca Ration, Florida, USA.

Khattab, Y.A. (2001). Effect of substituting black seed cake (Nigella sativa jl) for soybean meal in diets of Nile tilapia (Oreochromis niloticus 1.) on growth performance and nutrients utilization. Egypt. J. Aquat. Biol. \& Fish., 5 (2): 31- 46.

Lewis, R.M.; Emmans, G.C.; Dingwall, W.S. and Simm, G. (2002). A description of the growth of sheep and its genetic analysis. Anim. Sci., 74: 51-62.

Maunder, M.; MRichard B.; Deriso, K.M.; Schaefer, D.W.; Alexandre M.; Aires, S.; Carolina V.; Minte, V. and Steven E.C. (2017). A growth curve for species showing a near cessation in growth: application to bigeye tuna (Thunnus obesus) in the eastern pacific ocean. Inter.-American Tropical Tuna Commission, 1-12.

Metwally, M.A.A. (2009). Effects of garlic on some antioxidant activities in Tilapia nilotica .World Journal of Fish. and Marine Sciences, 1: 56-64.

Nadkarni, A.K. (1976). Indian material medica popular prakashan Pvt. Ltd., Bornbay, India.

Nandlal, S. and Pickering, T. (2004). Tilapia fish farming in Pacific island countries: Tilapia hatchery operation, Noumea, New Caledonia. PMid, 22 (1): 6-13.

Nwabueze, A. (2012). The Effect of Garlic (Allium sativum) on Growth and Haematological Parameters of Clarias gariepinus (Burchell, 1822). Sustainable Agriculture Research, 1 (2): 222-228.

Qatnan, K.A. and Al-Owafeir, M.A. (2014). Response of Nile tilapia Oreochromis niloticus to fed diets supplemented with graded levels of black seed Nigella sativa 1. stored under tropical conditions. J.Animal and Poultry Prod., Mansoura Univ., 5 (12): $605-618$.

Rawling, M.D.; Merrifield, D.L. and Davies, S.J. (2009). Preliminary assessment of dietary supplementation of Sangrovit ${ }^{\circledR}$ on red tilapia (Oreochromis niloticus) growth performance and health. Aquaculture, 294 (1-2): 118-122.

Sahu, S.; Das, B.K.; Mishra, B.K.; Pradhan, J.; Samal, S.K. and Sarangi, N. (2008). Effect of dietary Curcuma longa on enzymatic and immunological profiles of rohu, Labeo rohita (Ham.), infected with Aeromonas hydrophila. Aquaculture Res., 39: 1720-1730.

SAS. (2012). Version 90 SAS Institute Inc Cary NC.

Sönmez, A.Y.; Soner, B.; Mevlüt, A.; Sevdan, Y.; Gouranga, B.; Olcay, H. and Talat, Y. (2015). Effects of dietary supplementation of herbal oils containing 1,8-cineole, carvacrol or pulegone on growth performance, survival, fatty acid composition, and liver and kidney histology of rainbow trout (Oncorhynchus mykiss) Fingerlings. Turk. J. Fish. Aquat. Sci., 15: 813-819. 
Sieklicki, M.F.; PedrosA, V.B.; Rocha, C.G.; Moreira, R.P.; Falcao, P.R.; Santos, I.C.; Ferreira, E.M. and Martins, A. (2016). Growth curves of Texel male lambs. Acta Scientiae Vet., 44 (1396): 1-6.

Sveier, H.; Raae, A.J and Lied, E. (2000). Growth and protein turnover in Atlantic salmon (Samo salar L.); the effect of dietary protein level and protein particle size. Aquaculture, 185: 101-120.

Tariq, M.M.; Iqbal, F.; Eyduran, E.; Bajwa, M.A.; Huma, Z. E. and Waheed, A. (2013). Comparison of nonlinear functions to describe the growth in mengali sheep breed of Balochistan. Pakistan J. Zool., 45: 661-665.
Tekel, N.; Sireli, H.D.; Elicin, M. and Elicin, A. (2005). Comparison of growth curve models on Awassi lambs. Indian Vet. J., 82:179-182.

Topal, M.; Ozdemir M.; Aksakal, V.; Yildiz, N. and Dogru, U. (2004). Determination of the best nonlinear function in order to estimate growth in Morkaraman and Awassi Lambs. Small Rum. Res., 55: $229-232$.

\section{تأثير زيت حبة البركة على أداء النمو والاستفادة الغذائية ومقارنه معادلات غير خطية مختلفة مقابل النموذج الخطى لوصف منحنى النمو فى البلطى النيلى مانى

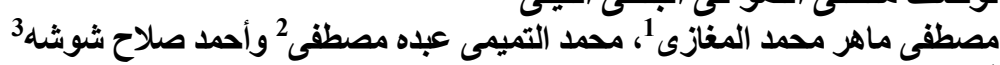

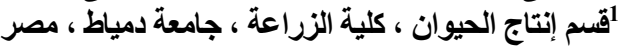

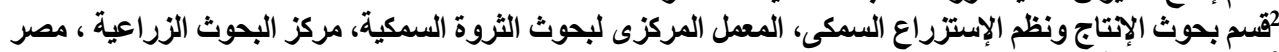

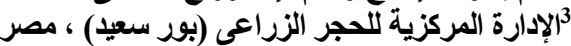

تم اجر اء هذه الدراسة لتقييم تأثير مستويات مختلفة من زيت حبة البركة على أداء البلطى النيلي و ومقارنة معادلات غير خطية مختلفة

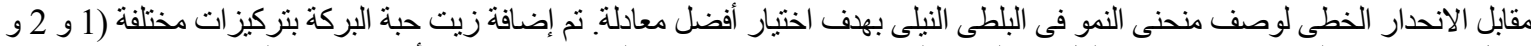

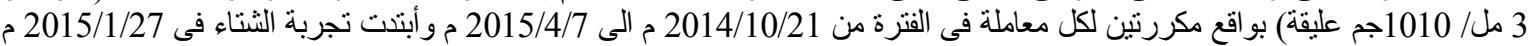

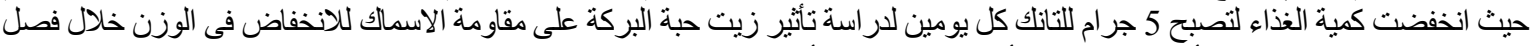

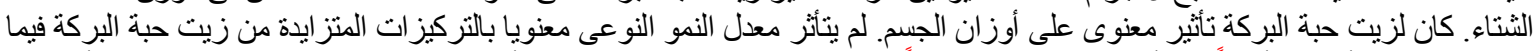

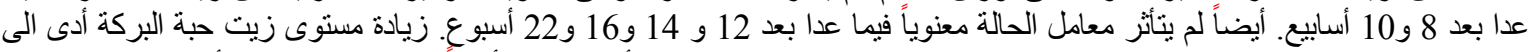

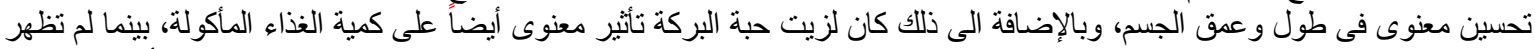

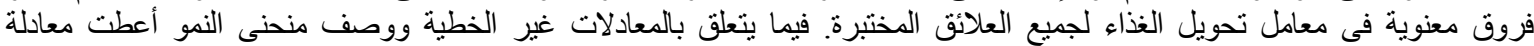

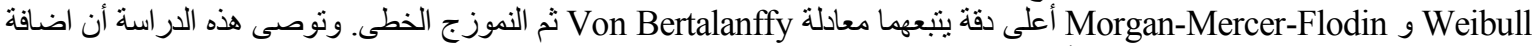

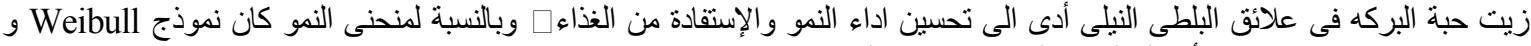
Morgan-Mercer-Flodin 